Cite As: NJ Waltham, RM Connolly (2013) Artificial tidal lakes: Built for humans, home for fish. Ecological Engineering 60:414-420

\title{
Artificial tidal lakes: built for humans, home for fish
}

\author{
Nathan J. Waltham ${ }^{1,2^{*}}$, Rod M. Connolly ${ }^{2}$ \\ ${ }^{1}$ Gold Coast City Council, PO Box 5042, Gold Coast Mail Centre, Queensland, 9729, \\ Australia \\ ${ }^{2}$ Australian Rivers Institute - Coasts and Estuaries, and School of Environment, \\ Griffith University, Gold Coast campus, Queensland, 4222, Australia \\ *Present Address. Australian Centre for Tropical Water and Aquatic Ecosystem Research \\ (TropWATER), James Cook University, Queensland, 4811, Australia \\ Tel.: +61 74781 4262; fax +61 47815589 \\ e-mail address: nathan.waltham@jcu.edu.au
}

\begin{abstract}
The construction of artificial, residential waterways to increase the opportunities for coastal properties with waterfrontage is a common and widespread practice. We describe the fish community from the world's largest aggregation of artificial, estuarine lakes, the Burleigh Lake system that covers 280 ha on the Gold Coast in Queensland, Australia. Fish were collected from 30 sites in winter and spring of one year, and water salinity was measured 3-monthly for a 10 year period. Fish are not present in deep, bottom waters and the intensive sampling focussed on the shallow waters around lake margins. The fish fauna consisted of 33 species. All but three species are marine species that can tolerate some brackishness. The other three are freshwater species, normally found in rivers but also occurring in the upper reaches of estuaries. Fish communities differed among the lakes, reflecting a weak gradient in salinity in lakes at different distances from the single connection to the natural estuary and thus marine waters. Overall, the deeper (to $28 \mathrm{~m}$ ), wider (700m) characteristics of lake estates, and their incorporation of partial barriers to tidal exchange with natural reaches of estuaries, remove some of the hydrological concerns with very extensive canal estates. The shallow lake margins are habitat for a subset of fish species inhabiting adjacent natural wetlands. Where the lakes occupy space that was formerly land, this is novel habitat for fish. In place, however, where lakes have replaced natural wetlands, further comparisons of fish in lake and adjacent natural wetlands will be useful.
\end{abstract}

Keywords: Fish, urbanization, canal estates, salinity, tidal lakes, water quality 
Cite As: NJ Waltham, RM Connolly (2013) Artificial tidal lakes: Built for humans, home for fish. Ecological Engineering 60:414-420

\subsection{Introduction}

To increase the extent of usable waterfrontage land in the coastal zone developers have been excavating large tracts of natural wetland (e.g. mangroves, saltmarsh) or digging out terrestrial habitat to create artificial, urban waterway developments (canal estates). A recent review highlighted the extent of canal proliferation for residential purposes (Waltham and Connolly, 2011). Globally, there are $>4000 \mathrm{~km}$ of these created waterways (more than the length of the Mississippi River). They are particularly prevalent around the coast of North America, including Florida which has the largest single aggregation $(1700 \mathrm{~km})$, but now occur on every inhabited continent (Waltham and Connolly, 2011). They are an increasingly conspicuous component of our coastlines, and what are known as "transitional waters" (Elliott and Whitfield, 2011).

In Australia, construction of canals has proliferated since the first, built in 1956, with more and more canals joined directly to natural estuaries or to the end of existing artificial systems (Johnson and Williams, 1989). For example, artificial urban waterways on the Nerang River estuary in Queensland alone have increased the original linear length of the estuary from $20 \mathrm{~km}$ to over $150 \mathrm{~km}$ (Waltham and Connolly, 2011). One consequence of this ongoing construction activity has been major hydraulic and erosion problems to downstream residential properties and bridge foundations. In response, waterway property developers altered the engineering to lake developments by separating the new system from the downstream waterway via a tidal control device (e.g. locks, weirs, gates, pipes). The design shift has allowed property developments to extend even further landward with minimal consequences on the downstream tidal prism (Zigic et al., 2005). These urban lakes now occupy 1 430 ha in Australia, and are also becoming a prominent feature of coastal developments elsewhere (Asia/Middle east 950 ha, North America 460 ha, Europe $138 \mathrm{ha}$ ). They now represent $5 \%$ of the total global extent of artificial urban waterways (Waltham and Connolly, 2011).

The engineering of these created waterways has taken two main designs: 1) open canal estates with direct tidal exchange with the downstream primary estuary, and 2) tidal lakes that are separated with the downstream estuary via a tidal control structure (e.g. weir, gate) (Waltham and Connolly, 2007). Despite these differences, both canals and lakes differ substantially from natural estuaries in that they generally lack aquatic vegetation (Connolly, 2003; Waltham and Connolly, 2006), have a depauperate benthic macroinvertebrate composition (Maxted et al., 1997), and have smooth, engineered, shorelines and unvegetated substrate (Morton, 1989). Water quality can be poor owing to the greater depth for navigation access, reduced circulation in highly ramified networks (many narrow branching arms) and high input loads of untreated urban stormwater (Maxted et al., 1997; Waltham, 2002). Preliminary evidence suggests that these impoverished conditions are more prevalent in lakes because of the imposed tidal restrictions compared to open, more connected 
Cite As: NJ Waltham, RM Connolly (2013) Artificial tidal lakes: Built for humans, home for fish. Ecological Engineering 60:414-420

canals (Waltham, 2002). We have previously shown that lakes support different fish assemblages than canals (Waltham and Connolly, 2007). The lakes surveyed in that study, however, were small ( $<5 \mathrm{ha}$ ) and generally well mixed, which prevented an adequate assessment of the factors underpinning fish distributions.

We surveyed the world's largest artificial, urban lake system (280 ha), the Burleigh Lakes system in southeast Queensland, Australia. The objectives were to: 1) describe the fish assemblage occupying the lake system; 2) examine the spatial arrangement of fish; and 3) determine whether the spatial pattern related to environmental factors considered important in natural estuaries. Our aims are to provide an overall description of fish assemblages occupying this increasingly prevalent form of built environment, and provide important data, where none currently exists, to assist managers balance engineering design with ecosystem function.

\subsection{Methods}

\subsection{Study area}

The Burleigh Lake system is located at the end of the Nerang River canal system $\left(28.083883^{\circ} \mathrm{S}, 153.418017^{\circ} \mathrm{E}\right.$; Fig. 1). The system has been progressively extended over the past 35 years and now exists as a single system consisting of 8 interconnecting lakes joined by narrow canals but with tidal exchange limited by shallow sand or concrete sills. Initially the lake creation replaced estuarine wetlands, but subsequently they were extended into terrestrial habitat. A tidal weir separates the entire system from the downstream Nerang River canals. The weir consists of 4 concrete gates (each $3 \mathrm{~m}$ long x $2 \mathrm{~m}$ high) programmed to open and close, allowing tidal exchange; $6 \mathrm{hr}$ flood and $6 \mathrm{hr}$ ebb flow, over two cycles per day. The opening of the weir is calculated to be $2 \mathrm{hr}$ after the high and low tide recorded at the nearest passageway to the open ocean. The delayed opening minimizes tidal currents through the gates and therefore erosion and damage to the infrastructure (Zigic et al., 2005). The lakes all have homogeneous shorelines of sand/mud substrate devoid of macrophytes. Lakes have maximum depths between 7 to $28 \mathrm{~m}$ and widths from 100 to $700 \mathrm{~m}$. 
Cite As: NJ Waltham, RM Connolly (2013) Artificial tidal lakes: Built for humans, home for fish. Ecological Engineering 60:414-420
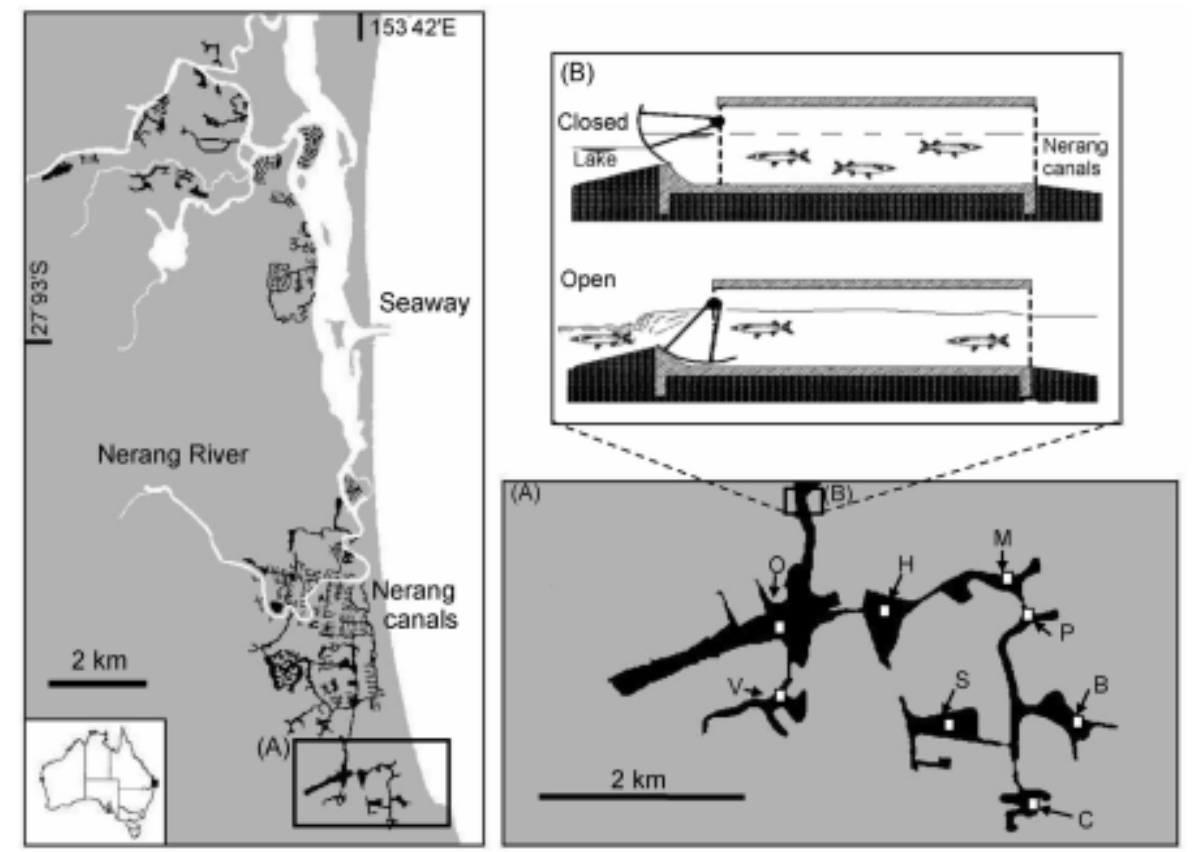

Fig. 1. Map showing the extent of artificial (black) and natural (original) waterway (white) of the Nerang River estuary. Sampling sites in the (A) Burleigh Lakes system: O, Lake Orr; V, Silvabank Lake; H, Lake Heron; M, Miami Lake; P, Pelican Lake; B, Burleigh Lake; S, Swan Lake and C, Burleigh Cove. White boxes are location of long-term water monitoring sites. (B) Cross-sectional view of the bidirectional weir (closed preventing fish movement between downstream canal estate and lakes, and open allowing fish movement between waterbodies) separating Burleigh Lake system from the Nerang River canals (modified from Zigic et al. 2005, with approval).

\subsection{Fish survey}

Fish were collected during the day in austral winter (July) and spring (October) of 2002, mid-way through the long-term water quality monitoring period, at 30 randomly chosen sites across the system. Each site was located at a different distance from the weir and measured using GIS software, taken as the shortest route by water. The intention was to examine fish abundance with environmental conditions at sites located at different distances from the weir (regression model), including dead-end lakes. Each site was also considered as a replicate within a lake (see Table 1 for number of samples per lake), and we could therefore analyse differences in fish assemblages among lakes (categorical). Initial sampling, using pop up ring nets and underway video cameras, in deep parts of lakes determined that no fish occurred on lake beds (Brickhill, 2009). We therefore subsequently limited fish surveys to the shallow margins of the lakes. Fish were caught, identified and counted using the pooled catch from two seine hauls per site (large seine: $70 \times 4 \mathrm{~m}, 18 \mathrm{~mm}$ stretch mesh; small seine: $5 \times 1 \mathrm{~m}, 1 \mathrm{~mm}$ stretch mesh). Fish data at nine of the sites (from Heron, Miami and Swan Lakes) were reported previously as part of a less intensive study comparing temporal differences among canals and lakes in southeast Queensland (Waltham and Connolly, 2007). At the same time, salinity, temperature, 
Cite As: NJ Waltham, RM Connolly (2013) Artificial tidal lakes: Built for humans, home for fish. Ecological Engineering 60:414-420

and dissolved oxygen (YSI 600) were measured at all sites immediately following fish sampling, $0.5 \mathrm{~m}$ below the surface. In natural estuaries, turbidity has been an important determinant of fish assemblages (e.g. Blaber and Blaber, 1980; Thiel et al, 1995), but it was low (2-25 NTU) here, and was therefore not considered further.

Non-metric multidimensional scaling (NMDS) was used to ordinate lakes (Lake Orr and Silvabank Lake were removed from analysis because of too few data points) from biotic similarity matrices using the Bray-Curtis index, on $4^{\text {th }}$ root transformed data. Fish assemblages were compared across lakes and season (both fixed) by PERMANOVA using the Bray-Curtis dissimilarity measure (Anderson, 2001). Similarity Percentages (SIMPER) identified which species contributed most to the difference (i.e. high mean/sd ratio; Clarke, 1993). BIOENV was used to assess relationships for single or combinations of environmental factors (recorded at the time of fish sampling) with the fish composition using the weighted Spearman coefficient $\left(\rho_{\mathrm{w}}\right)$ (Clarke and Ainsworth, 1993). Fish counts (for species observed at $>5$ sites), total abundance and species richness were $\log _{10}(\mathrm{x}+1)$ transformed because examination of raw fish data and environmental factors using scatter plots revealed an over emphasis in the distribution of counts at some sites and not others. Following transformation, scatter plots of residuals against predicted values revealed no clear relationship, consistent with the assumption of linearity. Also, the normal plot of regression standardized residuals for fish counts indicated a relatively normal distribution, indicating that this transformation was a suitable model for the dataset. Seasons were analysed separately. Distance from the tidal gate was excluded from analysis because it was collinear with salinity (winter $\mathrm{R}^{2}=0.73, \mathrm{P}=0.001$; spring $\left.\mathrm{R}^{2}=0.53, \mathrm{P}=0.006\right)$.

\subsection{Long term water quality monitoring}

Surface $(0.5 \mathrm{~m})$ water quality was measured for temperature, dissolved oxygen and salinity with a calibrated multiprobe (YSI 600) in 7 of the 9 lakes every 3 months for 10 years, May 1999 to Nov 2009, with sites located towards the centre of each lake (Fig. 1). These data are included here to provide context for the period in which fish were sampled.

\subsection{Results}

\subsection{Fish species composition}

In all, 10686 fish were caught, about half at each season, comprising 33 species from 19 families (Table 1). All but three of the species are also recorded from adjacent, natural estuarine wetlands. Fourteen species of economic importance in the region accounted for $35 \%$ of the total catch. The five species contributing $>5 \%$ of total combined catch by number were Favonigobius exquisitus (22\%),

Gobiopterus semivestitus (17\%), Herklotsichthys castelnaui (14\%), 
Cite As: NJ Waltham, RM Connolly (2013) Artificial tidal lakes: Built for humans, home for fish. Ecological Engineering 60:414-420

Table 1. Relative abundance (\%) of the common fish species, total abundance and species richness. Numbers in parentheses are \pm SE. (-) no catch; $\left(^{*}\right)$ denotes economically important species; (na) no common name. (X) species not recorded in natural wetland habitats including seagrass, mangrove, saltmarsh and muddy/sand flats in Moreton Bay (Blaber and Blaber, 1980; Morton et al. 1987; Weng, 1990;

\begin{tabular}{|c|c|c|c|c|}
\hline Family/species & Common Name & Winter & Spring & Natural wetlands \\
\hline \multicolumn{5}{|l|}{ AMBASSIDAE } \\
\hline Ambassis jacksoniensis & Port Jackson Glassfish & 5 & 18 & \\
\hline Ambassis marianus & Ramsay’s Glassfish & $<1$ & $<1$ & \\
\hline \multicolumn{5}{|l|}{ CARANGIDAE } \\
\hline Scomberoides lysan* & Queenfish & $<1$ & $<1$ & \\
\hline \multicolumn{5}{|l|}{ CLUPEIDAE } \\
\hline Herklotsichthys castelnaui* & Southern Herring & 3 & 25 & \\
\hline Nematalosa erebi* & Bony Bream & 1 & 3 & \\
\hline \multicolumn{5}{|l|}{ ELEOTRIDIDAE } \\
\hline Philypnodon grandiceps & Flat-Headed Gudgeon & $<1$ & $<1$ & $\mathrm{X}$ \\
\hline Hypseleotris compressus & Firetail Gudgeon & - & $<1$ & $\mathrm{X}$ \\
\hline \multicolumn{5}{|l|}{ ELOPIDAE } \\
\hline Elopes hawaiensis & Giant Herring & - & $<1$ & \\
\hline \multicolumn{5}{|l|}{ GERREIDAE } \\
\hline Gerres subfasciatus* & Silver Belly & 3 & 5 & \\
\hline \multicolumn{5}{|l|}{ GOBIIDAE } \\
\hline Favonigobius exquisitus & Exquisite Sand Goby & 29 & 14 & \\
\hline Gobiopterus semivestitus & Glass Goby & 25 & 7 & \\
\hline Redigobius macrostoma & Blue Spot Goby & 10 & 4 & \\
\hline Arenigobius bifrenatus & Bridled Goby & - & $<1$ & \\
\hline Pandaka lidwilli & na & 6 & 10 & \\
\hline Parkraemeria ornata & na & $<1$ & 1 & \\
\hline \multicolumn{5}{|l|}{ HEMIRAMPHIDAE } \\
\hline Arrhamphus sclerolepis krefftii* & Snub-Nosed Garfish & 1 & $<1$ & \\
\hline Hyporhamphus australis* & Eastern Garfish & $<1$ & $<1$ & \\
\hline \multicolumn{5}{|l|}{ MELANOTAENIIDAE } \\
\hline Pseudomugil signifer & Pacific Blue-Eye & 2 & 1 & \\
\hline \multicolumn{5}{|l|}{ MONODACTYLIDAE } \\
\hline Monodactylus argenteus & Butter-Bream & - & $<1$ & \\
\hline \multicolumn{5}{|l|}{ MUGILIDAE } \\
\hline Mugil cephalus* & Sea Mullet & 5 & 5 & \\
\hline Liza argentea* & Tiger Mullet & $<1$ & 1 & \\
\hline Mugil georgii* & Fantail Mullet & - & $<1$ & \\
\hline \multicolumn{5}{|l|}{ PLATYCEPHALIDAE } \\
\hline Platycephalus fuscus* & Northern Dusky Flathead & - & $<1$ & \\
\hline \multicolumn{5}{|l|}{ PLOTOSIDAE } \\
\hline Euristhmus lepturus & Longtailed Catfish Eel & - & $<1$ & \\
\hline \multicolumn{5}{|l|}{ SCATOPHAGIDAE } \\
\hline Selenotoca multifasciata & Striped Butterfish & $<1$ & $<1$ & \\
\hline \multicolumn{5}{|l|}{ SILLAGINIDAE } \\
\hline Sillago ciliata* & Sand Whiting & $<1$ & $<1$ & \\
\hline Sillago maculata* & Winter Whiting & $<1$ & - & \\
\hline \multicolumn{5}{|l|}{ SPARIDAE } \\
\hline Acanthopagrus australis* & Yellowfin Bream & 4 & 2 & \\
\hline Rhabdosargus sarba* & Tarwhine & $<1$ & $<1$ & \\
\hline \multicolumn{5}{|l|}{ SPHYRAENIDAE } \\
\hline Sphyraena obtusata & Striped Sea Pike & - & $<1$ & \\
\hline \multicolumn{5}{|l|}{ SYNGNATHIDAE } \\
\hline Hippichthys penicillus & Beady Pipefish & - & $<1$ & \\
\hline \multicolumn{5}{|l|}{ TETRAODONTIDAE } \\
\hline Marilyna pleurosticta & Banded Toadfish & $<1$ & $<1$ & \\
\hline Tetractenos hamiltoni & Common Toadfish & - & $<1$ & \\
\hline
\end{tabular}


Cite As: NJ Waltham, RM Connolly (2013) Artificial tidal lakes: Built for humans, home for fish. Ecological Engineering 60:414-420

$\begin{array}{lrr}\text { Total number of fish } & 5455 & 5231 \\ \text { Total number of fish species } & 25 & 32 \\ \text { Site average total fish abundance } & 181(32) & 120(24) \\ \text { Site average fish species richness } & 7(<1) & 9(<1)\end{array}$

Connolly, 1999; Thomas and Connolly, 1999; Johnson, 2010).

Ambassis jacksoniensis (11\%) and Pandaka lidwilli (9\%). The family Gobiidae dominated the catch, accounting for $73 \%$ and $38 \%$ in winter and spring respectively.

3.2 Patterns in fish assemblages among lakes and between seasons PERMANOVA indicated a significant difference between seasons $(\mathrm{F}=7.51, \mathrm{P}<$ 0.010) due to higher numbers of Herklotsichthys castelnaui during spring than winter (SIMPER; 10\% contribution), and higher numbers of Gobiopterus semivestitus and Favonigobius exquisitus during winter than spring (SIMPER; 9\% contribution by each species). Lakes were also significantly different $(\mathrm{F}=3.76, \mathrm{P}<0.001)$. The interaction term in the PERMANOVA was non-significant but low $(\mathrm{F}=1.4, \mathrm{P}=$ 0.108 ) and, on that basis, differences among lakes were examined separately for the two seasons.
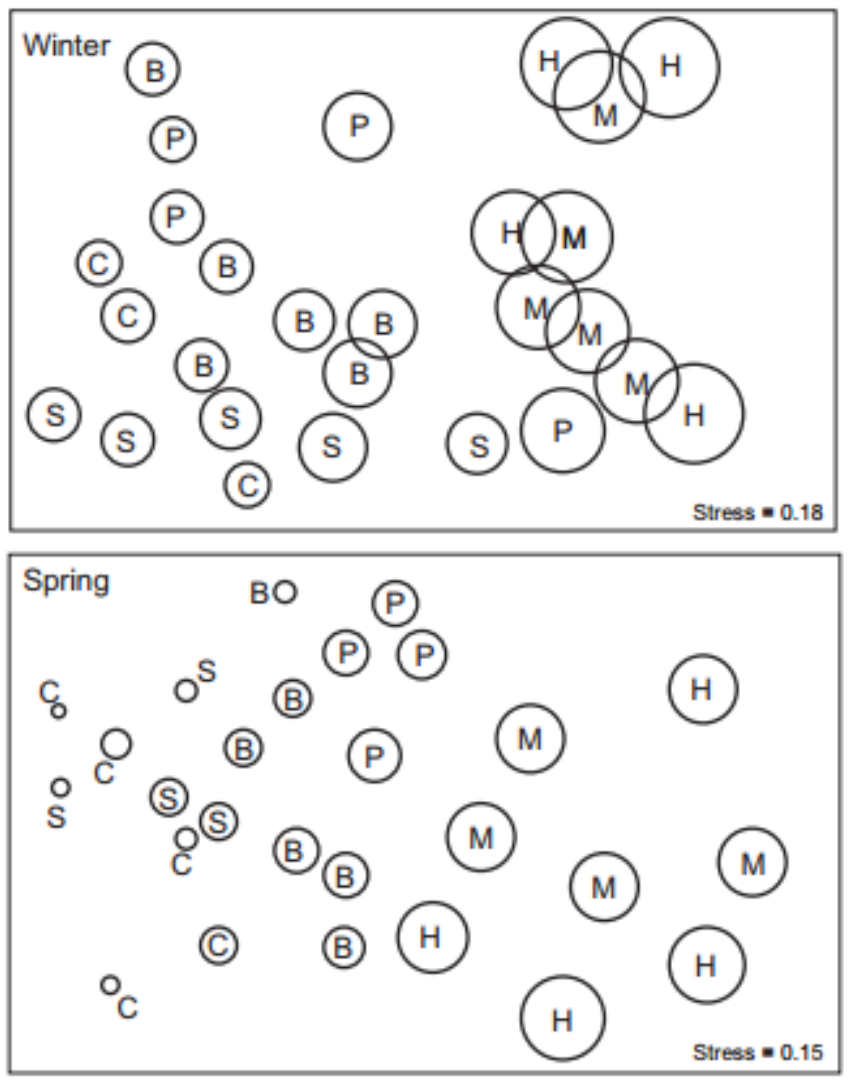

Fig. 2. Two-dimensional MDS ordination plots for winter and spring survey. Diameter of circle is proportional to salinity at the site; smallest circle $=21$, largest $=33$. Site abbreviations same as in Fig. 1 . 
Cite As: NJ Waltham, RM Connolly (2013) Artificial tidal lakes: Built for humans, home for fish. Ecological Engineering 60:414-420

In the winter survey, pairwise comparisons revealed significant separation of lakes into 3 groups: (1) Heron and Miami; (2) Pelican and Burleigh; and (3) Swan and Burleigh Cove $(\mathrm{P}<0.001$ in all cases, Fig. 2a). Favonigobius exquisitus (SIMPER 4 to $36 \%$ contribution), Gobiopterus semivestitus ( 9 to $32 \%$ ) and

Redigobius macrostoma ( 6 to $21 \%$ ) were the main species separating lake groups.

In the spring survey, pairwise comparisons revealed the significant separation of lakes into 4 groups: 1) Heron and Miami; 2) Pelican; 3) Burleigh; and; 4) Swan and Burleigh Cove ( $\mathrm{P}<0.043$ in each case, Fig. 2b). Favonigobius exquisitus (SIMPER 3 to $34 \%$ contribution), Herklotsichthys castelnaui (10 to $25 \%$ ) and Ambassis marianus (17 to 37\%) were the main species separating lake groups.

\subsection{Environmental factors and relationships with fish}

In both winter and spring, salinity accounted for most of the variation in assemblage composition among lakes, with slightly more species and a higher total abundance in lakes furthest from the weir and thus with lower salinity (Fig. 2; winter BIOENV, $\rho_{\mathrm{w}}=0.28$; spring BIOENV, $\rho_{\mathrm{w}}=0.18$ ). Water temperature and dissolved oxygen were similar among lakes and contributed little to explaining multivariate fish assemblage patterns.

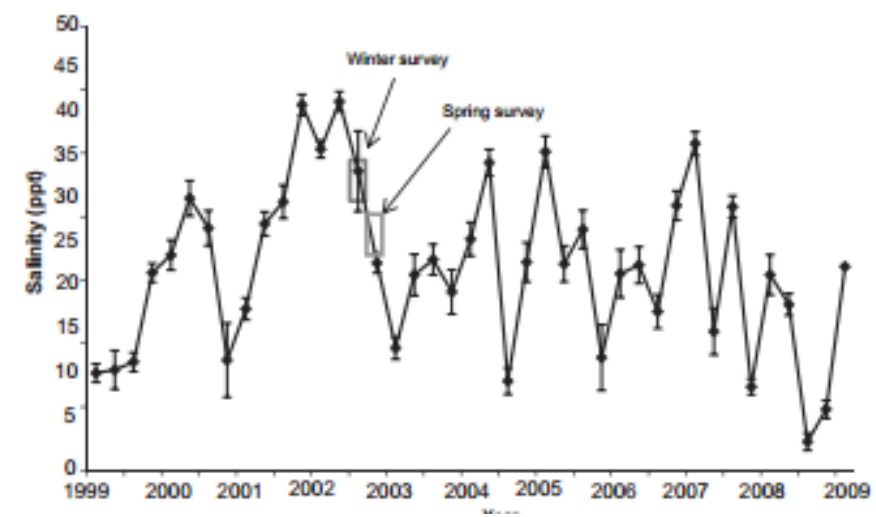

Fig. 3. Temporal changes in surface $(0.5 \mathrm{~m})$ salinity using rolling mean $( \pm \mathrm{SE})$ for all lakes pooled from 1999 to 2009 . Shaded area is the salinity range corresponding with the both fish surveys in 2002 .

Few regression relationships existed between fish abundances and environmental factors, and when detected, they were weak. In winter, a greater total abundance of Favonigobius exquisitus was found at sites with higher temperature $\left(\mathrm{R}^{2}=0.15\right.$, $\mathrm{P}=0.039$ ). In spring, a higher total abundance of Herklotsichthys castelnaui and Nematalosa erebi occurred at sites with low salinity $\left(\mathrm{R}^{2}=0.31, \mathrm{P}=0.001 ; \mathrm{R}^{2}=0.37\right.$, $\mathrm{P}=0.001$ respectively), while Gerres subfasciatus numbers were highest at sites with warmer water temperature $\left(\mathrm{R}^{2}=0.22, \mathrm{P}=0.009\right)$. 
Cite As: NJ Waltham, RM Connolly (2013) Artificial tidal lakes: Built for humans, home for fish. Ecological Engineering 60:414-420

\subsection{Long term water quality in lakes}

Assessment of long-term rolling mean salinity revealed that the overall lake system fluctuates between 4 and 42 (Fig. 3), with a cycle of higher salinity during winter and lower during summer.

\subsection{Discussion}

\subsection{Fish community in urban lakes}

The Burleigh Lake system supports many fish species common in adjacent natural wetland habitats, including species harvested commercially and recreationally. An important finding here is that the tidal control gate has the mutual benefit of allowing extension to the existing network of waterfront real estate, while clearly also permitting fish access upstream, unlike some drainage channels or constructed systems elsewhere (e.g. Poulakis et al., 2002; Richardson et al., 2011; Boys and Williams, 2012). The lack of fish in the cooler, deeper waters of the system probably reflects the low dissolved oxygen concentrations common in deep sections (Brickhill, 2009). Instead, fish are found along the shallow waters at lake margins, and many are widespread, even occupying dead-end areas that are often considered depauperate (Morton, 1989; Lincoln-Smith et al., 1995; Maxted et al., 1997). Overall, the fish fauna in this system consists predominantly of a subset of species reported from nearby natural estuarine habitats. The exceptions are Philypnodon grandiceps and Hypseleotris compressus, which have not been recorded from the natural wetlands of this region (Johnson, 2010). Both are freshwater species recorded rarely in estuaries, usually only when washed downstream during periods of high rainfall (Allen et al., 2002). The presence of these two freshwater species in Burleigh Lakes, as well as the other freshwater species that has been recorded in other estuarine habitats in the region, is a sign that the fish fauna of these lakes are more typical of an upper estuarine reach.

\subsection{Factors structuring fish distribution}

Among the possible environmental factors contributing to the structure of fish community in estuaries, salinity is the most regularly reported (e.g. Marshall and Elliott, 1998; Whitfield and Elliott, 2002; Martino and Able, 2003; Barletta et al., 2005; Franca et al., 2011). These studies showing a strong association between salinity and fish communities are from surveys of entire estuaries, covering the full oceanic to freshwater gradient. In the Burleigh Lake system, although it is large (10 $\mathrm{km}$ long), it represents only part of the overall Nerang River estuary, which has longer natural sections and much longer canal sections. The salinity gradient within the Burleigh Lake system essentially reflects the gradient within the lower to mid reaches of the estuary overall, and therefore accounts for a subsection of the full salinity gradient typically studied by other authors in natural estuaries. Freshwater runoff can rapidly change salinity across entire natural estuarine systems. Such changes can be abrupt and therefore directly affect fish in estuaries (e.g. Gordo and Cabral, 2001; Garcia et al., 2003; Rhodes-Ondi and Turner, 2009). In the present study, the fish 
Cite As: NJ Waltham, RM Connolly (2013) Artificial tidal lakes: Built for humans, home for fish. Ecological Engineering 60:414-420

surveys were done during periods where salinity was approximately in the middle to high end of the range for this system. Salinity at times can be higher and lower than experienced during the fish survey, and can change rapidly, more so than the nearby Nerang River estuary (Waltham, 2002), suggesting that this lake functions as a single, well mixed, system. The effects of salinity on fish in estuaries and their classification into freshwater, estuarine and marine groups has recently been revised (Whitfield et al., 2012). The fishes reported in our surveys were predominantly marine species that have penetrated up the estuary. The occurrences of bony bream (Nematalosa erebi) and the two gudgeon species (Philypnodon grandiceps, Hypseleotris compressus) are notable, however, since they are considered freshwater species (Allen et al., 2002), albeit all being also recorded from estuaries. Possibly these specimens might be residual individuals remaining after earlier, fresher periods (Kimmerer, 2002). Additional long term fish data including over periods of much lower salinities would be informative, and would ultimately allow better predictions of fauna likely to be in the lake system at any particular time.

In natural estuaries, water temperature has been shown to contribute to the structuring of fish assemblages (e.g. Thiel et al., 1995; Connolly 1997; Marshall and Elliott, 1998). In the Burleigh Lake system, temperature made only a very minor contribution, perhaps because it varied little across the system. Other factors not measured during the survey might also affect the distribution of fish. In the Elbe Estuary, Germany, factors other than salinity correlating with fish community patterns included organic load, heavy metal and organochlorine concentrations in the water (Thiel et al., 1995). Pollutant concentrations have only recently been measured in artificial lakes for the first time (Waltham et al., 2011). Concentrations are on average low, but variable, and such measurements in conjunction with fish distributions would be worth examining in the future, particularly given the global extent of these built waterways (Waltham and Connolly, 2011). 
Cite As: NJ Waltham, RM Connolly (2013) Artificial tidal lakes: Built for humans, home for fish. Ecological Engineering 60:414-420

Table 2. Summary of environmental factors, total species and total abundance for each lake in winter (2002) and spring (2002) (mean, \pm SE). Lakes ordered in increasing distance from weir. $\mathrm{N}=$ sample size. $(-)=$ no sample collected. Lake abbreviations as for Figure 1.

\begin{tabular}{|c|c|c|c|c|c|c|c|c|}
\hline \multirow[b]{2}{*}{ Season/variable } & \multicolumn{8}{|l|}{ Lake } \\
\hline & $\mathrm{O}$ & $\mathrm{H}$ & $\mathrm{V}$ & $\mathrm{M}$ & $\mathrm{P}$ & $\mathrm{B}$ & $\mathrm{C}$ & $\mathrm{S}$ \\
\hline Winter & $(\mathrm{n}=1)$ & $(\mathrm{n}=4)$ & & $(\mathrm{n}=5)$ & $(n=4)$ & $(\mathrm{n}=6)$ & $(\mathrm{n}=3)$ & $(\mathrm{n}=5)$ \\
\hline Temperature $\left({ }^{\circ} \mathrm{C}\right)$ & 16 & $17(0.4)$ & - & $17(0.2)$ & $16(0.3)$ & $17(0.1)$ & $16(0.1)$ & $16(0.2)$ \\
\hline Salinity & 33 & $32(0.5)$ & - & $31(0.2)$ & $30(0.1)$ & $29(0.1)$ & $29(0.3)$ & $28(0.1)$ \\
\hline $\mathrm{DO}(\mathrm{mg} / \mathrm{L})$ & 7 & $9(0.4)$ & - & $7(0.5)$ & $8(0.4)$ & $8(0.5)$ & $7(0.1)$ & $8(0.2)$ \\
\hline Total fish species & 6 & $5(2)$ & - & $7(<1)$ & $8(<1)$ & $8 \quad(<1)$ & 8 (2) & $10 \quad(<1)$ \\
\hline Total fish abundance & 164 & $294(155)$ & - & $107 \quad(48)$ & $178 \quad(42)$ & $228 \quad(79)$ & $201 \quad(85)$ & $161 \quad(72)$ \\
\hline Spring & $(n=1)$ & $(n=4)$ & $(\mathrm{n}=2)$ & $(n=4)$ & $(n=4)$ & $(\mathrm{n}=6)$ & $(n=5)$ & $(n=4)$ \\
\hline Temperature $\left({ }^{\circ} \mathrm{C}\right)$ & 23 & $25(1.3)$ & $25(0.1)$ & 23 & 25 & $25(0.1)$ & $(0.2)$ & $24(0.6)$ \\
\hline Salinity & 27 & $26(0.3)$ & $26(0.5)$ & $26(0.4)$ & $24(0.1)$ & $24(0.4)$ & $24 \quad(0.5)$ & $21(0.2)$ \\
\hline $\mathrm{DO}(\mathrm{mg} / \mathrm{L})$ & 6 & $6(1.2)$ & $6(0.1)$ & $6(0.3)$ & $6(1.0)$ & $5.6(2.8)$ & $5.3(0.8)$ & $5.8(0.6)$ \\
\hline Total fish species & 5 & $6(<1)$ & 8 (1) & $7(<1)$ & 9 (1) & $9 \quad(<1)$ & 10 & $11(<1)$ \\
\hline Total fish abundance & 16 & $202(107)$ & 189 & $182(76)$ & $171(132)$ & $256(14)$ & $274 \quad(12)$ & $178(14)$ \\
\hline
\end{tabular}


Cite As: NJ Waltham, RM Connolly (2013) Artificial tidal lakes: Built for humans, home for fish. Ecological Engineering 60:414-420

\subsection{Engineering artificial urban lakes}

The engineering change in waterway developments to tidally controlled lakes presents new and extended habitat opportunities for fish. Where the lakes are excavated from land, completely novel fish habitat is created. This is essentially a role reversal from the more common practice of land reclamation, more accurately referred to as "land claim" (Adam, 2002), in which landfill is used to make terrestrial habitat in the sea. Where artificial lakes replace natural estuarine wetlands, however, the net outcome for fish is likely to be poor, since natural wetlands most often support vegetated habitats known to support higher abundances of fish than unvegetated habitats (Connolly, 1994). A rigorous test of differences in fish assemblages between artificial lake and natural vegetated wetlands would be very useful.

A fundamental hydrological difference in the design of lakes compared to open canal estates is a much longer residence time resulting from the tidal restrictions. Waltham et al. (2011) found that the reduced flushing contributed to accumulation of metal and pesticide contaminants in water and sediment, a function that probably acts as an effective means of protecting downstream waterways through the sequestration of contaminants. Deeper lake areas have high nutrient and faecal bacteria and low dissolved oxygen concentrations, a pattern consistent with urban waterbodies more broadly (Maxted et al., 1997; Mitsch 2005; Collins et al., 2010). Concerns such as these in the extensive canals of Florida reduced the aesthetic amenity and thus property values of properties along entire canal estate developments. The Florida state government implemented strategies to enhance and protect the socioeconomic and ecological benefits of these systems (Kruczynski, 1999), but their effectiveness does not appear to have been monitored.

\subsection{Conclusion}

Evidence from the Burleigh Lake system, the largest artificial estuarine lake system in the world, shows that estuarine lakes built for residential purposes provide alternative wetland habitat for a variety of fish living in adjacent estuarine reaches. As in natural estuaries, salinity is the primary determinant of fish distributions in shallow waters on lake margins, though the association is driven by a few species sensitive to salinity. A shift from canal to lake estates for hydrological and engineering reasons will nevertheless provide opportunities for aquatic fauna. Consideration of tidal connectivity and water quality, including salinity, should help to meet the demands of social and economic goals while optimizing opportunities for fish. The design of artificial lakes has overcome some hydrodynamic limitations of very extensive canal estates. The margins of these lakes provide habitat for fish. This is unlikely to be of overall benefit to fish where the lakes replace natural wetlands. Where the lakes are excavated from terrestrial habitat, however, there is a net gain in fish habitat.

\section{Acknowledgements}


Cite As: NJ Waltham, RM Connolly (2013) Artificial tidal lakes: Built for humans, home for fish. Ecological Engineering 60:414-420

Gold Coast City Council funded the surveys, J. Johnson from Queensland Museum assisted with fish identification, and M. Brickhill provided comments on the manuscript. Two reviewers provided valuable comments which helped improve this manuscript. Field sampling complied with Australian Law.

\section{References}

Adam, P., 2002. Saltmarshes in a time of change. Environ. Conserv. 29, 39-61. Allen, M. L., Gerald, R., Midgley, S. H., Allen, M., 2002. Field guide to the freshwater fishes of Australia. Western Australian Museum, Australia.

Anderson, M. J., 2001. A new method for non-parametric multivariate analysis of variance. Aust. J. Ecol. 26, 32-46.

Barletta, M., Barletta-Bergan, A., Saint-Paul, U., Hubold, G., 2005. The role of salinity in structuring the fish assemblages in a tropical estuary. J. Fish Biol. $66,45-72$.

Blaber SJM, Blaber TG (1980) Factors affecting the distribution of juvenile estuarine and inshore fish. J. Fish Biol. 17, 143-162.

Boys, C. A., Williams, R.J., 2012. Succession of fish and crustacean assemblages following reinstatement of tidal flow in a temperate coastal wetland. Ecol. Eng. 49, 221-232.

Brickhill, M. L. A., 2009. Enhancement of fish stock by habitat manipulation in artificial waterways. Dissertation completed for fulfillment of $\mathrm{PhD}$, Griffith University, Australia.

Clarke, K. R., 1993. Non-parametric multivariate analyses of changes in community structure. Aust. J. Ecol. 18, 117-143.

Clarke, K.R., Ainsworth, M., 1993. A method of linking multivariate community structure to environmental variables. Mar. Ecol. Prog. Ser. 92, 205-219.

Collins, K. A., Lawrence, T. J., Stander, E. K., Jontos, R. J., Kaushal, S. S., Newcomer, T. A., Grimm, N. B., Cole Ekberg, M. L., 2010. Opportunities and challenges for managing nitrogen in urban stormwater: A review and synthesis. Ecol. Eng. 36, 1507-1519.

Connolly, R. M., 1994. A comparison of fish assemblages from seagrass and unvegetated areas of a southern Australian estuary. Aust. J. Mar. Freshw. Res. 45, 1033-1044.

Connolly, R. M., 1997. Differences in composition of small, motile invertebrate assemblages from seagrass and unvegetated habitats in a southern Australian estuary. Hydrobiologia 346, 137-148.

Connolly, R. M., 1999. Saltmarsh as habitat for fish and nektonic crustaceans: challenges in sampling designs and methods. Aust. J. Ecol. 24, 422-430.

Connolly, R. M., 2003. Differences in trophodynamics of commercially important fish between artificial waterways and natural coastal wetlands. Estuar. Coast. Shelf Sci. 58, 929-936.

Elliott, M., Whitfield, A. K., 2011. Challenging paradigms in estuarine ecology and management. Estuar. Coast. Shelf Sci. 94, 306-314. 
Cite As: NJ Waltham, RM Connolly (2013) Artificial tidal lakes: Built for humans, home for fish. Ecological Engineering 60:414-420

Franca, S., Costa, M. J., Cabral, H. N. 2011. Inter-and intra-estuarine fish assemblage variability along the Portuguese coast. Estuar. Coast. Shelf Sci. 91, 262-271.

Garcia, A.M., Vieira, J.P., Winemiller, K.O., 2003. Effects of 1997-1998 El Nino on the dynamics of the shallow water fish assemblage of the Patos Lagoon Estuary (Brazil). Estuar. Coast. Shelf Sci. 57, 489-500.

Gordo, L. S., Cabral, H. N., 2001. The fish assemblage structure of a hydrologically altered coastal lagoon: the Obidos lagoon (Portugal). Hydrobiologia 459, 125133.

Johnson, J., 2010. Fishes of the Moreton Bay Marine Park and adjacent continental shelf, Queensland, Australia. Memoirs of the Queensland Museum, 54(3) 299-353.

Johnson, T. C., Williams, S. H., 1989. From canals to lakes in south-east Queensland (Australia): water quality aspects. Water Sci. Technol. 21, 261-265.

Kimmerer, W. J., 2002. Physical, biological and management responses of variable freshwater flow into the San Francisco estuary. Estuaries 25, 1275-1290.

Kruczynski, W.L., 1999. Water Quality Concerns in the Florida Keys: Sources, Effects and Solutions. Environmental Protection Agency, Florida.

Lincoln-Smith, M. P., Hawes, P. M. H., Duque-Portugal, F. J., 1995. Spatial variability in the nekton of a canal estate in southern New South Wales, Australia, and its implications for estuarine management. Mar. Freshw. Res. 46, 715-721.

Marshall, S., Elliott, M., 1998. Environmental influences on the fish assemblage of the Humber Estuary, U.K. Estuar. Coast. Shelf Sci. 46, 175-184.

Martino, E. J., Able, K.W., 2003. Fish assemblages across the marine to low salinity transition zone of a temperate estuary. Estuar. Coast. Shelf Sci. 56, 969-987.

Maxted ,J. R., Eskin, R.A., Weisberg, S.B., Chaillou, J. C., Kutz, F. W., 1997. The ecological condition of dead-end canals of the Delaware and Maryland coastal bays. Estuaries 20, 319-327.

Mitsch, W.J. 2005. Applying science to conservation and restoration of the world's wetlands. Water Sci. Technol. 51, 13-26.

Morton, R.M., 1989. Hydrology and fish fauna of canal developments in an intensively modified Australian estuary. Estuar. Coast. Shelf Sci. 28, 43-58.

Poulakis, G. R., Shenker, J. M., Taylor, D. S., 2002. Habitat use by fishes after tidal reconnection of an impounded estuarine wetland in the Indian River Lagoon, Florida (USA). Wetl. Ecol. Manag. 10, 51-69.

Rhodes-Ondi, S. E., Turner, R. L., 2009. Salinity tolerance and osmatic response of the estuarine hermit crab Pagurus maclaughlinae in the Indian River Lagoon, Florida. Estuar. Coast. Shelf Sci. 86, 189-196.

Richardson, C. J., Flanagan, N. E., Ho, M., Pahl, J. W., 2011. Integrated stream and wetland restoration: A watershed approach to improved water quality on the landscape. Ecol. Eng. 37, 25-39. 
Cite As: NJ Waltham, RM Connolly (2013) Artificial tidal lakes: Built for humans, home for fish. Ecological Engineering 60:414-420

Thiel, R., Sepulveda, A., Kafemann, R., Nellen, W., 1995. Environmental factors as forces structuring the fish community of the Elbe Estuary. J. Fish Biol. 46, 47-69.

Thomas, B. E., Connolly, R. M., 2001. Fish use of subtropical saltmarshes in Queensland, Australia: relationships with vegetation, water, depth and distance onto the marsh. Mar. Ecol. Prog. Ser. 209, 275-288.

Waltham, N.J., Connolly, R.M., 2011. Global distribution and extent of artificial urban waterways. Estuar. Coast. Shelf Sci. 94, 192-197.

Waltham, N.J., Teasdale, P.R., Connolly, R.M., 2011. Contaminants in water, sediment and fish from natural and artificial residential waterways in southern Moreton Bay. J. Environ. Monit. 13, 3409-3419.

Waltham, N.J., Connolly, R.M., 2007. Artificial waterway design affects fish assemblage in urban estuaries. J. Fish Biol. 71, 1613-1629.

Waltham, N.J., Connolly, R.M., 2006. Trophic strategies of garfish, Arrhamphus sclerolepis, in natural coastal wetlands and artificial urban waterways. Mar. Biol. 148, 1135-1141.

Waltham, N. J., 2002. Health of the Gold Coast Waterways. Gold Coast City Council, Australia.

Weng, H. T., 1990. Fish in shallow areas in Moreton Bay, Queensland and factors affecting their distribution. Estuar. Coast. Shelf Sci. 30, 569-578.

Whitfield, A.K., Elliott, M., 2002. Fishes as indicators of environmental and ecological changes within estuaries: a review of progress and some suggestions for the future. J. Fish Biol. 61, 229-250.

Whitfield, A. K., Elliott, M., Basset, A., Blaber, S. J. M., West R. J., 2012. Paradigms in estuarine ecology: A review of the Remane diagram with a suggested revised model for estuaries. Estuar. Coast. Shelf Sci. 97, 78-90.

Zigic, S., King, B.A., Lemckert, C., 2005. Modelling the two dimensional flow between an estuary and lake connected by a bi-directional hydraulic structure. Estuar. Coast. Shelf Sci. 63, 33-41. 